\title{
Negritude: a Poem Written When Everything Else Fails to Translate
}

In Hayden's translation of Senghor's "T wo Flutes" it is the mayflies image that handles the stress

in translation from French to American idiom

Senghor (President of Senegal) and co-founder of Negritude

is angling for the French Academy[Aimé Césaire is not angling on his island]

though Gorée is just off the coast

There is a hustler named Ted Joans (a black American) reading his jazz poems across the Continent

his search for venues his newest song caught in his knapsack for he is homeless while traveling

Senghor is out of his own country on a visit to France (though he is the president-there has been no coup d'etat in his absence)

\section{What is Negritude the Academy senators ask of Senghor?}

Gorée \& Martinique he answers \& writes the original "T'wo Flutes" in French

meanwhile Hayden mentions kalaam without translation a stringed instrument so beautiful its vernacular cannot be copied

the reader is asked to approximate this song there is a hint in the title

allegory dualism symbolic geography idiomatic text $\&$ the singer caught amidst mayflies 


\section{[the silence of Negritude \\ caught at the Sorbonne}

\section{8 studied there \\ on the Seine \& its islands and bridges}

\section{in the 'city of light' many border crossings}

where all is dark as night]

["Negritude," a worldwide movement of the African diaspora usually attributed to Aimé Césaire and Léopold Sédar Senghor, on and off the continent of Africa, and answerable, by metaphor, to the violation of the African Slave Trade, better known as the "Triangular Trade." Robert Hayden, a translator of "Two Flutes," is also author of the modern epic, "Middle Passage," a poem written in eight dramatic voices assembled to place rhetorical blame on the complicity of the many agents of profit, large and small.] 